\title{
Diferensiasi Kebijakan Polandia dalam Menghadapi Migran Ekonomi dan Pengungsi
}

\author{
Rizky Anandita, Fadia Ayunabila Safitri, \\ Dasa Safitri, Rahmatul Amalia N. A.
}

\author{
Departemen Hubungan Internasional \\ Universitas Airlangga
}

\begin{abstract}
ABSTRAK
Isu migrasi kian menjadi pusat perhatian bagi negara-negara Uni Eropa sehubungan dengan adanya kebijakan Uni Eropa yang berupaya mendistribusikan tanggung jawab penerimaan imigran dan pengungsi secara merata antara negara-negara anggota. Polandia sebagai salah satu negara anggota Uni Eropa dihadapkan pada dua permasalahan, yakni penolakan masyarakat terhadap masuknya imigran dari luar Uni Eropa dan tekanan dari Uni Eropa untuk mematuhi kuota pengungsi. Kajian ini membahas mengenai respon kebijakan Polandia dalam menghadapi permasalahan-permasalahan yang telah disebutkan. Kajian ini menyimpulkan bahwa terdapat beragam faktor yang memengaruhi kalkulasi kebijakan imigrasi Polandia, yaitu: 1) faktor lingkungan; 2) budaya dan identitas; 3) pendidikan; 4) adanya asumsi "Trojan Horse"; serta 5) ketidakpuasan penduduk lokal. Kelima faktor tersebut menentukan persepsi masyarakat dan pemerintah Polandia terhadap isu migrasi.
\end{abstract}

Kata-kata kunci: Polandia, Imigrasi, Diferensiasi Kebijakan Imigrasi, Uni Eropa

The issue of migration has become a center of attention for European countries, especially among the members of the European Union. The significance of this issue has increased as a result to the efforts made by the supranational organization to redistribute the responsibility to accept immigrants and refugees evenly among member states. Poland, as a member state of the European Union faces two problems, the resistance shown by Polish society against the entrance of immigrants from outside European Union countries and the pressure given by the European Union to adhere to the refugee quota. This discussion attempts to explain the policies taken by Poland in responding the aforementioned problems. The research carried out in this discussion has shown that there are various factors that influence Poland's immigration policy calculation, namely: 1) societal factor; 2) culture and identity; 3) education; 4) a "Trojan Horse" assumption; and 5) the dissatisfaction of locals. These factors determine the perception of the Polish society and government towards migration.

Keywords: Poland, Immigration, Immigration Policy Differentiation, European Union 


\section{Pendahuluan}

Polandia telah memutuskan untuk membuka perbatasannya dalam mengatasi isu kekurangan tenaga kerja. Hal ini berlawanan dengan pernyataan Perdana Menteri Polandia yang mempertahankan kebijakan anti-migran dan mengatakan bahwa negara tersebut tidak dapat menerima pengungsi. Pernyataan tersebut telah menunjukkan penentangan Polandia terhadap ancaman tindakan hukum oleh Uni Eropa terhadap negara-negara yang gagal mematuhi kuota pengungsi (Dearden 2017). Keputusan Polandia untuk menolak pengungsi merupakan respons terhadap komitmen Uni Eropa untuk melakukan relokasi 160.00o pengungsi dari Yunani dan Italia. Penolakan terhadap rencana yang dirancang untuk mengurangi tekanan pada kedua negara tersebut menempatkan Polandia pada posisi yang bertentangan dengan Komisi Eksekutif Uni Eropa, yang telah membuka prosedur pelanggaran kepada Hungaria dan Polandia (The Associated Press 2017). Terkait hal ini, Hungaria dan Polandia telah mengabaikan desakan Jerman dan negara-negara lain untuk menerima migran di bawah sistem kuota atau meninggalkan Uni Eropa. Namun, opini publik di kedua negara tersebut juga menentang keras paksaan untuk menerima ribuan migran dari Afrika dan Timur Tengah.

Otoritas Polandia juga secara rutin menolak para pencari suaka di perbatasan Belarus dan Polandia dan mengembalikan mereka ke Belarus. Sejak tahun 2016, sejumlah besar pencari suaka yang umumnya berasal dari Republik Chechnya Rusia, Tajikistan, dan Georgia telah mencoba mengajukan permohonan suaka kepada Polandia di perbatasan Belarus (Human Rights Watch 2017). Menteri Urusan Internal Polandia, Mariusz Błaszczak, menyatakan bahwa Polandia tidak akan menerima pengungsi dari Republik Chechnya Rusia karena dianggap sebagai ancaman bagi keamanan nasional (Human Rights Watch 2017). Salah satu alasan banyak pihak di Polandia menolak untuk menerima migran adalah adanya pandangan bahwa migran akan menjadi masalah bagi masyarakat Polandia yang homogen (Cienski 2017). Polandia merupakan salah satu negara yang paling homogen di Eropa. Dilihat dari aspek demografis, populasi negara tersebut didominasi oleh orang Polandia dan penganut Katolik Roma. Rezim komunis yang pernah menguasai Polandia turut memberikan pengaruh terhadap proses imigrasi di negara tersebut. Pengaruh tersebut terwujud dalam kebijakan migrasi yang ketat. Faktor-faktor historis tersebut telah membentuk persepsi masyarakat Polandia kontemporer mengenai migrasi dan imigran secara umum (Behtane 2016). Pemimpin partai Hukum dan Keadilan, Jaroslaw Kaczyński, berpendapat bahwa dengan menerima migran, maka Polandia akan secara otomatis mendorong perubahan budaya dan menurunkan tingkat keamanan negara secara radikal (Cienski 2017). Pemerintah Polandia beranggapan bahwa Uni 
Eropa dan badan eksekutifnya, Komisi Eropa, tidak memiliki 'mandat perjanjian' untuk memaksa negara-negara anggota yang berdaulat untuk menerima pengungsi di negaranya.

Polandia juga menekankan posisinya bahwa pengambilan keputusan untuk menerima pengungsi dipegang oleh masing-masing negara, bukan Uni Eropa. Para pejabat Polandia berulang kali mengatakan bahwa meskipun menolak kedatangan pengungsi, Polandia mendukung mereka yang membutuhkan dengan meningkatkan bantuan kemanusiaan kepada korban perang di Suriah dan bekerja dengan organisasi yang memfasilitasi bantuan untuk membangun rumah sakit (Radio Poland 2018). Alasan lain Polandia untuk menolak relokasi pengungsi adalah adanya penerimaan sekitar satu juta pengungsi yang berasal dari Ukraina oleh negara tersebut, meskipun nyatanya jumlah pengungsi tidak sebanyak itu. Sebagian besar orang Ukraina di Polandia merupakan migran ekonomi dengan visa kerja di negara tersebut (Chapman 2016). Mantan Perdana Menteri Polandia, Beata Szydlo, mengatakan bahwa membantu dengan cara tersebut tidak hanya lebih murah tetapi juga lebih efektif apabila dibandingkan dengan kebijakan migrasi Uni Eropa yang tidak menghentikan gelombang tambahan migran ke Eropa. Setelah melalui pertimbangan, keputusan Hungaria dan Polandia kemudian mendapatkan dukungan dari Uni Eropa. Hal ini didorong oleh masyarakat Eropa yang umumnya tidak setuju akan imigrasi dan menentang keras beberapa pemimpin Eropa yang tetap memaksakan kebijakan imigrasi yang dianggap gagal. Selain itu, program relokasi dalam tingkat krisis yang dialami Eropa juga tidak menjamin terwujudnya situasi yang stabil.

Namun di tahun 2018, Polandia melakukan perubahan terhadap kebijakan imigrasinya. Negara tersebut memutuskan untuk membuka perbatasannya dengan tujuan untuk mengatasi isu ketenagakerjaan. Tingkat pengangguran di Polandia telah jatuh ke rekor terendah sejak tahun 1990, mendorong upah yang lebih tinggi dan memicu timbulnya kekhawatiran akan inflasi (Harper 2018). Imigrasi dengan demikian menjadi opsi yang krusial bagi pasar tenaga kerja dan perekonomian Polandia secara keseluruhan. Pasar tenaga kerja Polandia telah menerima sekitar satu juta migran Ukraina dalam kurun waktu tiga hingga empat tahun terakhir. Tanpa adanya pekerja asing, pertumbuhan GDP Polandia tidak akan mencapai tingkatan yang tinggi seperti pada tahun 2017, ketika pertumbuhan GDP negara tersebut mencapai 4,6 persen. Menteri Tenaga Kerja Polandia, Stanislaw Szwed, menjelaskan bahwa akan terdapat amandemen yang berisikan cara untuk memfasilitasi pekerja imigran dari luar Uni Eropa (Shah 2018). Salah satu isi dari amandemen tersebut adalah poin mengenai perpanjangan masa tinggal pekerja berdasarkan kualifikasi. Dengan amandemen tersebut, pemerintah Polandia berencana untuk mempermudah proses 
kedatangan, pemerolehan izin kerja, dan perpanjangan durasi tinggal bagi penduduk non-Uni Eropa. Saat ini, periode izin kerja yang dapat diajukan adalah tiga tahun. Namun hal ini dapat diperpanjang hingga lima tahun. Di bawah aturan baru, pasangan dari seseorang yang telah memiliki izin sah tidak perlu mengajukan permohonan. Daftar negara yang warganya dapat memperoleh manfaat dari aturan baru juga akan diperpanjang.

Kebanyakan dari kedatangan pekerja yang telah disebutkan meliputi pekerja-pekerja migran dari negara-negara Asia Tenggara, seperti Vietnam atau Filipina (Shah 2017). Pemerintah Polandia menerima informasi bahwa orang-orang yang berasal dari Asia Tenggara cenderung cepat dalam menyesuaikan diri dan berintegrasi dengan baik di Polandia. Namun hal yang harus dihadapi Polandia adalah masih banyaknya permintaan tenaga kerja dalam produksi, logistik, konstruksi, dan banyak lowongan lain yang tidak dapat diisi. Polandia memandang bahwa terdapat dua masalah utama dalam imigrasi. Permasalahan yang pertama berhubungan dengan birokrasi dan lambatnya proses aplikasi, sedangkan permasalahan yang kedua adalah habisnya kemungkinan untuk menemukan tenaga kerja dari industri tertentu di Ukraina (Shah 2018). Imigrasi dari Ukraina merupakan salah satu isu utama dalam pasar Polandia. Hal ini dikarenakan adanya fakta bahwa mayoritas pekerja asing di Polandia berasal dari Ukraina. Polandia merupakan satu di antara negara-negara Uni Eropa yang memiliki penyerapan tenaga kerja yang dibuka untuk Ukraina. Sebagian besar dari warga Ukraina yang memilih untuk bekerja di Polandia merupakan migran ekonomi berusia produktif yang tertarik dengan prospek untuk mendapatkan penghasilan hingga lima kali lipat lebih banyak dibanding pendapatan di Ukraina (Harper 2018). Pengusahapengusaha di Polandia juga mencari pekerja yang berasal dari Ukraina dikarenakan tidak adanya karyawan lokal yang tersedia dan adanya ketergantungan empat puluh persen perusahaan Polandia pada Ukraina dalam hal penjualan dan pelayanan. Merujuk pada hal tersebut, kurangnya sumber daya manusia dari Ukraina berdampak besar pada pertumbuhan ekonomi Polandia sehingga mendorong negara tersebut untuk memberlakukan kebijakan open border, yang membuka kesempatan bagi pekerja non-Uni Eropa untuk masuk ke Polandia.

Dalam beberapa tahun terakhir, imigran mulai memainkan peran penting dalam pasar tenaga kerja Polandia. Kehadiran imigran, bagaimanapun, juga menciptakan tantangan bagi struktur kelembagaan Polandia (Behtane 2016). Pasalnya, kerangka kerja institusional Polandia untuk menerima imigran, khususnya kebijakan integrasi, belum sepenuhnya dikembangkan (Duszczyk dan Góra dalam Behtane 2016). Permasalahan pengungsi di Eropa kemudian menimbulkan prospek bagi reformasi di Polandia dalam menjalankan proses yang 
dibutuhkan untuk menghasilkan kebijakan imigrasi yang lebih efektif. Jika tatanan global harus dipertahankan, negara-negara harus menyepakati siapa dan apa yang boleh menyeberangi pemburu nasional, serta bagaimana hal tersebut dilakukan. Uni Eropa sendiri memiliki hubungan global yang terstruktur di sekitar aliran liberal perdagangan, modal, dan pembatasan migrasi. Akan tetapi, lonjakan migrasi yang tidak teratur saat ini memungkinkan munculnya kekuatan imigran untuk menantang dan mengubah tatanan global.

Orang bermigrasi karena beberapa aspek, seperti geografis, ekonomi, budaya dan sosial-politik. Alasan-alasan tersebut juga meliputi faktorfaktor penarik dan faktor-faktor pendorong. Faktor penarik adalah faktor-faktor di negara tujuan yang menarik individu atau kelompok untuk meninggalkan rumah mereka. Faktor-faktor tersebut dikenal sebagai utilitas tempat, yang merupakan keinginan tempat yang menarik orang. Peluang ekonomi yang lebih baik, lebih banyak pekerjaan, dan janji kehidupan yang lebih baik seringkali menarik orang ke lokasi baru. Adapun faktor pendorong adalah faktor yang memaksa individu untuk bergerak secara sukarela, dan dalam banyak kasus, mereka dipaksa karena individu mengambil risiko sesuatu jika mereka tetap tinggal. Faktor pendorong mungkin termasuk konflik, kekeringan, kelaparan, atau aktivitas keagamaan ekstrem (Wasik 2016).

Untuk faktor penarik, jika menilik dari dari dinamika isu migrasi dan kaitannya dengan labour market, Polandia merupakan salah satu negara anggota Uni Eropa yang memiliki tingkat emigrasi yang secara tidak proporsional jauh lebih tinggi dibandingkan dengan imigrasi di abad 20. Sejalan dengan realitas geografis, Polandia berkembang menjadi negara transit para migran dan menjadi negara tujuan, utamanya bagi negara-negara tetangganya di perbatasan bagian timur seperti Ukraina, Belarus, Rusia, serta negara pecahan Uni Soviet lain. Kemudian, sejalan dengan keberhasilan integrasi negara tersebut ke dalam Uni Eropa pada Mei tahun 2004, Polandia secara gencar melakukan open-borders. Jumlah para pekerja Polandia yang bermigrasi ke negara UE seperti Inggris, Jerman, serta Irlandia semakin meningkat secara signifikan. Saat tersebut menjadi salah satu arus emigrasi terbesar dalam sejarah postwar Polandia serta menjadikannya salah satu negara pengirim buruh terbesar di Uni Eropa. Situasi tersebut menjadi tantangan besar bagi stabilitas domestik Polandia, yang juga telah mengalami penurunan tingkat kelahiran dalam satu dekade terakhir (Iglicka dan Ziolek-Skrzypczak 2010). Akan tetapi, sejak 2004 hingga 2006, Polandia memberlakukan aturan perizinan khusus untuk tempat tinggal sebagai bentuk adopsi kebijakan migrasi berdasarkan standar UE. Hal ini senada dengan Iglika dan Ziolek-Skrzypczak (2010) yang menyatakan bahwa jumlah perizinan untuk bertempat tinggal semakin berkurang, sedangkan perizinan untuk berpergian secara 
sementara meningkat di lebih dari 5.000 orang antara tahun 2004 dan 2009.

Seiring dengan implementasi dari aturan restriksi terhadap para migran ini, Polandia memperoleh ketidakseimbangan dalam migrasi. Ketidakseimbangan ini ditunjukkan dengan adanya penurunan pada tingkat arus imigrasi secara berlanjut hingga mencapai angka negatif. Salah satu penyebab rendahnya angka imigrasi ke Polandia adalah adanya pandangan di kalangan imigran dari Uni Eropa bahwa Polandia tidak cukup menarik untuk dikunjungi dan ditinggali. Hal ini dikarenakan oleh kemampuan ekonomi Polandia yang tidak memerlukan pekerja baru dalam jumlah besar, sehingga masyarakat di dalamnya melakukan perpindahan. Dalam situasi tersebut, dapat dipahami bahwa negara tanpa secara eksplisit menyatakan keberpihakannya dalam menentukan siapa saja yang dapat masuk dan menetap di wilayah teritorialnya. Sistem dapat secara alamiah melakukan hal tersebut. Dalam kasus Polandia, bagaimanapun, keanggotaan dalam Uni Eropa merupakan hal yang menunjukkan bagaimana rezim negara dan regionalisme pada awalnya telah melakukan sekuritisasi dengan menentukan siapa dan berapa orang yang dapat masuk ke dalam negara dan kawasan serta bagaimana hal tersebut diatur dalam suatu mekanisme. Akan tetapi, tentu saja imigrasi dalam konteks tenaga kerja berbeda dengan konteks penerimaan para imigran yang terdiri atas pengungsi baik legal maupun ilegal. Meskipun begitu, posisi geografis Polandia yang cukup strategis sebagai wialayah transit antara Barat dan Timur tetap mendorong banyak migran dari Eropa Timur seperti Ukraina, belarus, Armenia, Rusia dan Moldova, serta Asia, khususnya Vietnam untuk melakukan transit.

Terjadinya krisis ekonomi global tahun 2008 mengakibatkan penurunan GDP Polandia serta meningkatnya pengangguran dari 9,5 persen pada perempat pertama tahun 2008 hingga 11,9 persen pada perempat keempat tahun 2009. Namun, dibandingkan dengan negara Uni Eropa lainnya, Polandia merupakan negara yang melakukan pemulihan ekonomi dengan cukup cepat dan tidak jatuh hingga titik resesi. Hal ini yang menyebabkan diaspora Polandia di Inggris serta Irlandia tertarik untuk kembali ke home country mereka (Iglicka dan Ziolek-Skrzypczak 2010). Polandia menjadi salah satu negara Uni Eropa yang berkembang dengan cepat. Sejak tahun 2016, ekonomi Polandia mengalami pertumbuhan sebesar 2,1 persen dan diprediksi akan mengalami pertumbuhan sebesar 3 persen di tahun 2017-2018. Berdasarkan data terakhir dari the European Job Mobility Portal, pada perempat pertama tahun 2017 sebesar 57,9 persen dari jumlah total pekerja bekerja dalam bidang jasa, 31,75 persen di bidang industri, dan 11,2 persen di sektor agrikultur. Menurut Polish Labour Force Survey, dalam beberapa tahun terakhir terdapat pertumbuhan secara bertahap dalam jumlah 
masyarakat yang bekerja. Akan tetapi, di luar pertumbuhan ekonomi yang dilihat melalui kuantitas GDP, secara lebih spesifik labor market Polandia mengalami beberapa masalah yang sifatnya sementara, seperti peningkatan jumlah pengangguran dalam beberapa bulan di awal dan akhir tahun. Sejumlah 55\% dari masyarakat yang tidak bekerja belum menyelesaikan pendidikan menengah, 1 dari 4 orang tidak memiliki pengalaman pekerjaan, 3 dari 10 tidak memiliki kualifikasi profesional, serta hampir $40 \%$ telah terdaftar sebagai pengangguran selama 1 tahun (European Commission 2017). Apabila dilihat dari adanya tantangan ini, keterbukaan dalam menerima tenaga kerja kemudian dapat menjadi salah satu solusi cepat untuk mendapatkan tenaga kerja sesuai dengan kualifikasi yang dibutuhkan dalam sektor-sektor pekerjaan di Polandia, yang pada dasarnya menawarkan kesempatan kerja yang cukup luas.

Urgensi akan keterbukaan perbatasan untuk pekerja migran juga terlihat dengan merujuk pada situasi domestik Polandia yang pada realitasnya menghadapi penurunan sumber daya manusia, baik tenaga kerja kasar maupun staf profesional. Dilansir dari Reuters (2017), Polandia sedang mengalami kekurangan tenaga kerja kasar untuk pembangunan infrastruktur yang didanai oleh Uni Eropa di tahun 20182020. Sebagian besar pekerja kasar tersebut telah memilih untuk bekerja di negara-negeraa Eropa Barat untuk mendapatkan upah yang lebih tinggi. Rata-rata upah yang diterima oleh pekerja Polandia di negara UE lainnya berkisar mulai 3.000 hingga 4.000 euro per bulan, sementara di Polandia tidak terdapat investor yang bersedia untuk menawarkan upah sebesar nilai tersebut. Rata-rata upah yang dapat ditawarkan di Polandia sendiri kurang lebih 1.096 euro setiap bulan. Minimnya jumlah pekerja mendorong kebutuhan akan imigrasi, bahkan double immigration, untuk mencegah pencabutan investasi asing (Koper dan Florkiewicz 2017). Pada tahun 2018, sebuah perusahaan konstruksi membutuhkan sekian ribu pekerja asing dan khawatir bahwa Polandia tidak dapat menyelesaikan beberapa mega proyek. Selain itu, dalam sektor publik hampir dua pertiga pimpinan sektor publik membutuhkan sejumlah pegawai baru. Akan tetapi, sangat sedikit masyarakat yang tertarik untuk bekerja di kantor publik (Bartyzel 2018). 


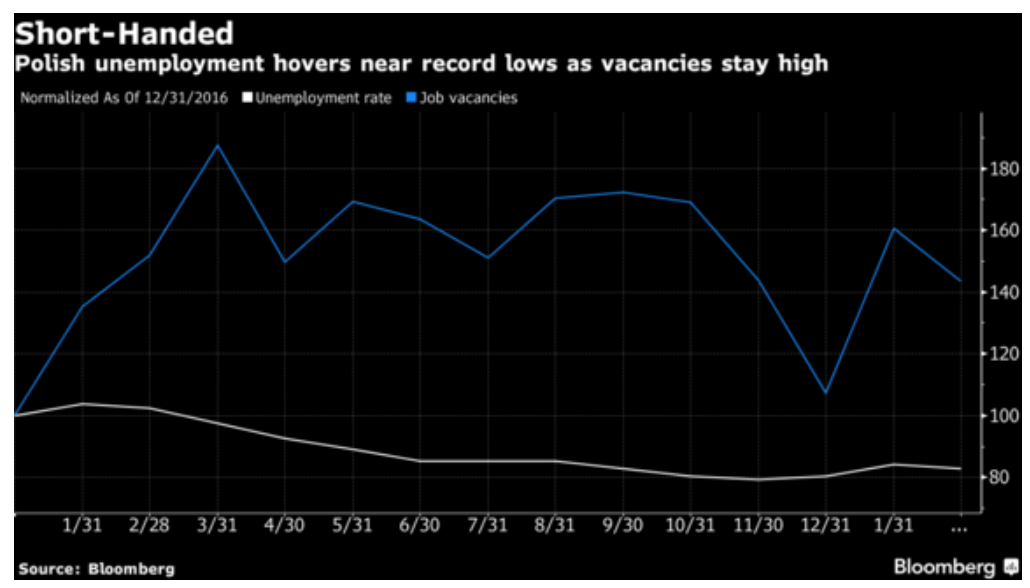

Grafik 1. Tingkat Perbandingan Angka Pengangguran dan Ketersediaan Lapangan Kerja

Grafik di atas menunjukkan perbandingan antara tingkat lowongan pekerjaan di Polandia yang cukup tinggi di tahun 2016 dengan tingkat pengangguran yang konsisten cukup rendah. Kondisi di atas merupakan bentuk urgensi penerimaan imigran. Dalam merespon urgensi tersebut, bagaimanapun, Polandia menghadapi dilema terkait dengan asal imigran. Dilema ini disebabkan oleh adanya fakta bahwa sebagian besar imigrasi pada beberapa waktu terakhir diisi oleh warga negara atau bahkan pencari suaka dari negara-negara konflik. Hal tersebut menjadi justifikasi pemerintah Polandia untuk tetap melakukan restriksi terhadap migrasi. Padahal, kapabilitas Polandia dalam melakukan screening dan dibutuhkannya ribuan tenaga kasar memiliki cost yang lebih tinggi dibandingkan dengan hanya berfokus dalam mencegah masuknya imigran dari negara-negara yang tidak dikehendaki. Bahkan, merujuk pada Kennan (2016), keuntungan potensial yang dapat diperoleh dari dibukanya perbatasan cukup tinggi. Apabila seluruh negara maju menghapuskan semua restriksi legal dalam imigrasi, keuntungan yang dapat diperoleh kurang lebih sebanding dengan pendapatan rata-rata orang di satu negara yang kurang maju. Meskipun arus migrasi yang dipredisikan berjumlah besar dalam kaitannya dengan jumlah pekerja di negara pengirim, pada kenyataaannya justru pengaruh yang ditimbulkan terhadap upah asli cenderung kecil. Pihak oposisi yang menolak ide arus bebas tenaga kerja mendasarkan asumsinya pada pandangan atau prediksi bahwa imigrasi akan dapat menjatuhkan nilai upah yang sebenarnya di host country.

Adapun faktor pendorong dari dinamika migrasi pekerja dapat dilihat pada kasus pengungsi Afghanistan. Warga Afghanistan saat ini merupakan kelompok terbanyak kedua yang datang ke Eropa, ditunjukkan dengan kedatangan baru sejumlah lebih dari 20.000 orang 
ke UE pada bulan Agustus 2015 (Parkes 2015). Kebanyakan orang secara logis berasumsi bahwa para pengungsi ini melarikan diri dari kekerasan Taliban yang bangkit kembali. Namun dalam kenyataannya, banyak migran berasal dari Iran, yang merupakan negara dengan posisi sebagai kekuatan regional yang muncul dengan pertumbuhan ekonomi cukup baik selama bertahun-tahun. Iran memiliki diaspora Afghanistan sekitar 1,4 juta, lebih dari dua pertiga di antaranya adalah pengungsi dan tidak memiliki surat resmi (Parkes 2015). Dari awal 2015, Teheran menempatkan para pengungsi ini pada kondisi "limbo" atau berada pada masa tidak menentu untuk menunggu keputusan resolusi. Dengan kata lain, pemerintah Iran masih tidak memastikan untuk memberikan perpanjangan masa tinggal mereka. Ketidakpastian tersebut mendorong banyak warga Afghanistan untuk melanjutkan perjalanan mereka ke Turki dan menuju Uni Eropa (Parkes 2015).

Selain itu, permasalahan migrasi di Polandia juga terkait dengan pengungsi Suriah. Pengungsi dari Perang Sipil Suriah, atau Pengungsi Suriah, adalah warga negara dan penduduk tetap dari Republik Arab Suriah yang telah melarikan diri dari negara mereka sejak awal Perang Saudara Suriah pada tahun 2011 dan telah mencari suaka di bagian lain dunia. Pada 2016, dari perkiraan populasi sebelum perang 22 juta, PBB mengidentifikasi 13,5 juta warga Suriah yang membutuhkan bantuan kemanusiaan, yang terdiri atas lebih dari 6 juta pengungsi internal di dalam Suriah dan sekitar 5 juta pengungsi di luar Suriah. Sebagian besar yang terakhir ini diselenggarakan oleh negara-negara tetangga Suriah (UNHCR 2016). Di antara negara-negara Regional Refugee and Resilience Plan (3RP), sebagai sebuah platform koordinasi bagi negaranegara tetangga, dengan pengecualian Israel dan Mesir, UNHCR menyebutkan bahwa terdapat 5,165,502 pengungsi terdaftar pada Agustus 2017. Turki adalah negara tuan rumah terbesar bagi pengungsi, terdaftar dengan lebih dari 3,5 juta pengungsi Suriah. UNHCR juga menyebutkan bahwa terdapat hampir 1 juta pencari suaka di Eropa per Agustus 2017. Hal ini menunjukkan bahwa stabilitas politik yang terganggu di Suriah telah mengancam keselamatan banyak dari rakyatnya. Hal tersebut menjadi faktor pendorong bagi warga Suriah untuk pergi meninggalkan Suriah guna memperoleh perlindungan dan kehidupan yang lebih baik. Posisi Polandia saat dihadapkan dalam isu tersebut adalah memilih untuk menolak adanya imigran, yang dalam hal ini merujuk pada pengungsi dari daerah berkonflik. 


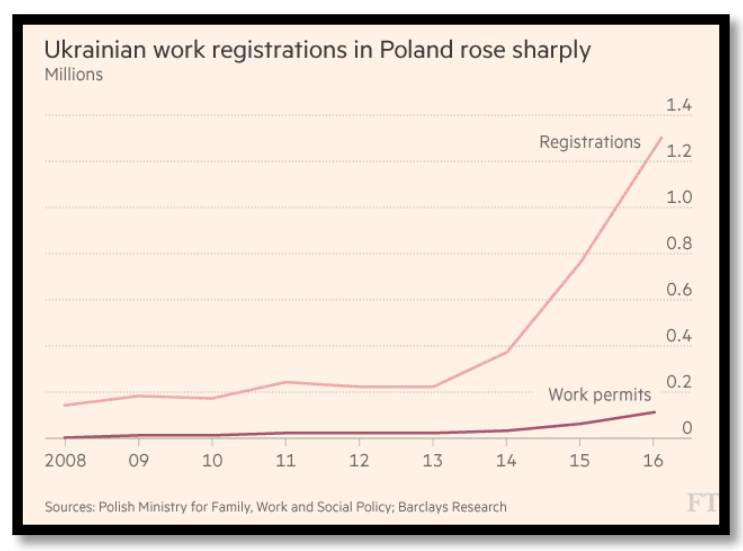

Grafik 2. Peningkatan Tenaga Kerja Ukraina di Polandia

Hampir 1,3 juta warga Ukraina pada tahun 2015 menerima pendaftaran kerja sementara yang diberikan Polandia, sementara 116.0oo lainnya menerima izin kerja jangka panjang. Kedua angka tersebut meningkat enam kali lipat sejak 2013, didorong terutama oleh kemerosotan ekonomi yang mengikuti revolusi pro-Barat Ukraina tahun 2014 dan konflik Rusia di bagian timur negara tersebut (Wasik 2016). Ekonomi di Ukraina masih terhambat oleh perang dan korupsi sehingga cenderung lamban. Sementara itu, Polandia memiliki pertumbuhan yang tidak terganggu dan bahkan kekurangan tenaga kerja. Selain itu juga terdapat fakta bahwa banyak orang Polandia lebih memilih untuk mencari mata pencaharian di Eropa Barat. Bisnis di Ukraina pun berjalan tidak stabil, sehingga semakin sulit bagi para pekerja untuk mempertahankan pekerjaan mereka di Ukraina. Mayoritas para migran usia kerja tertarik oleh prospek mendapatkan upah lima kali lebih banyak dari pada yang dapat mereka peroleh dari jenis pekerjaan yang sama di Ukraina. Hal ini terjadi karena adanya devaluasi tajam mata uang Ukraina (Cragg 2018).

Petinggi Hukum dan Keadilan Nasional Polandia menyebutkan bahwa arus masuk imigran dari Ukraina terbukti bermanfaat secara politik dan ekonomi. Hal tersebut membantu menangkis kritik Uni Eropa atas penolakan Polandia untuk menerima kuota bagi para migran Timur Tengah dan untuk mengisi kekurangan tenaga kerja setelah pemulangan dua juta orang Polandia yang mencari upah lebih tinggi di Eropa Barat, kekurangan yang bisa diperburuk oleh kebijakan pemerintah jika terus meminimalisasi jumlah migran yang masuk ke Polandia (Wasik 2016). Seperti yang disebutkan sebelumnya, hubungan budaya yang dekat dan persamaan linguistik, bahkan jika kedua negara memiliki hubungan yang rumit, memudahkan imigran Ukraina untuk berasimilasi. Faktanya, tidak seperti eksodus Suriah, sebagian besar pendatang Ukraina bukanlah pengungsi yang melarikan diri dari daerah timur yang 
dilanda perang. Lebih dari 6.000 orang Ukraina telah mencari suaka di Polandia sejak tahun 2014 (Wasik 2016). Migrasi yang merupakan sebuah bentuk perpindahan penduduk dapat didasari oleh berbagai alasan. Imigrasi memiliki berbagai macam, baik yang bersifat sementara maupun permanen. Keberadaan imigran sendiri sebelumnya tidak menjadi masalah bagi Polandia. Bahkan respon yang dimiliki oleh warganya terhadap imigran di negaranya cenderung positif. Akan tetapi, Polandia mulai memiliki perubahan terhadap kedatangan imigran setelah memuncaknya konflik Suriah yang berakibat pada instabilitas keamanan negara-negara kawasan Timur Tengah serta tidak terkecuali, negara-negara anggota Uni Eropa. Instabilitas keamanan yang dimaksud salah satunya bersumber dari kedatangan pengungsi dari konflik Suriah. Polandia menolak keputusan yang ditetapkan oleh Uni Eropa terkait kuota penerimaan pengungsi yang datang dari Timur Tengah dan Afrika Utara untuk setiap negara Uni Eropa (Euronews 2018).

Penolakan yang dilakukan oleh Polandia ini bukanlah sebuah fenomena baru. Banyak negara yang menolak untuk menerima pengungsi. Polandia menunjukkan sikap positif terhadap pengungsi dari Ukraina, yang kedatangannya disebabkan oleh konflik bersenjata yang terjadi di wilayah tersebut. Sikap positif terhadap pengungsi, bagaimanapun, mengalami penurunan ketika ditanya mengenai pengungsi yang berasal dari wilayah Timur Tengah. Dalam kasus penerimaan kelompok pengungsi dari Timur Tengah, identitas agama yang dibawa oleh para pengungsi memberikan pengaruh signifikan dalam penolakan yang ditunjukkan oleh masyarakat Polandia. Inti permasalahan yang ada dalam kasus ini adalah ketakutan yang dimiliki masyarakat terhadap kebudayaan yang dimiliki oleh pengungsi yang datang (Bachman 2016). Konflik sendiri dapat muncul sebagai akibat dari identitas yang dimiliki. Identitas yang dimiliki seseorang pada dasarnya merupakan cara orang tersebut melihat dirinya sendiri. Proses identifikasi inilah yang membedakan antara satu orang dengan orang lain, karena keanggotaan terhadap satu identitas membuat seseorang tidak tergabung ke dalam identitas lainnya. Identitas yang ada merupakan hal yang dapat menggabungkan seseorang ke dalam sebuah kolektivitas yang terdiri atas individu-individu dengan identitas yang sama. Identitas yang dimiliki juga menimbulkan terhadap sebuah bentuk kebudayaan yang tumbuh dalam keadaan yang dimilikinya (Eckert 2006, 22).

Identitas Muslim yang dibawa oleh para pengungsi ini menimbulkan ketakutan pada warga Polandia, yang mayoritasnya menganut agama Katolik. Ketakutan ini didasari oleh adanya kemungkinan hilangnya identitas yang dimiliki masyarakat Polandia. Kehilangan identitas merupakan permasalahan besar, karena kehilangan identitas juga berarti kehilangan hal yang mendefinisikan diri seseorang atau suatu 
kelompok (Eckert 2006, 23). Kendati datang dalam jumlah yang dapat dikatakan kecil, kehadiran pengungsi yang menganut agama Islam menimbulkan rasa takut di masyarakat akan perubahan kebudayaan yang dibawanya. Hal ini dapat dibandingkan dengan masyarakat Ukraina, yang secara kultural tidak berbeda jauh dengan masyarakat Polandia (Bachman 2016). Ekonomi juga merupakan salah satu isu yang diangkat dalam pembahasan mengenai masuknya imigran. Pasalnya, kedatangan imigran dapat berdampak pada ekonomi Polandia secara keseluruhan. Keadaan ekonomi yang dimiliki oleh Polandia dirasa tidaklah cukup untuk menampung imigran. Keberadaan dan potensi yang dimiliki oleh imigran dalam mendorong produktivitas suatu negara merupakan hal penting. Penerimaan imigran dapat dijadikan sebagai respon terhadap menurunnya angka kelahiran yang dimiliki. Namun, perekonomian Polandia yang tergolong rendah secara rata-rata jika dibandingkan dengan negara-negara UE lainnya menjadi dasar bagi penolakan Polandia terhadap penanggungan pengungsi secara kolektif yang diatur dalam kebijakan UE (Bachman 2016).

Suara yang kuat dalam penolakan terhadap masuknya imigran sendiri terdapat pada ancaman keamanan yang dapat ditimbulkan oleh kelompok pengungsi yang datang. Keberadaan imigran ditakutkan dapat menyebabkan ancaman keamanan berupa kejahatan (Bachman 2016). Kejahatan tersebut dapat berupa konflik yang muncul akibat perselisihan yang terjadi antara kelompok imigran dengan masyarakat asli. Hal ini dapat timbul dari penempatan keberadaan imigran sebagai kambing hitam dalam berbagai permasalahan yang terjadi pada masyarakat asli. Namun, hal yang sama juga dapat terjadi pada kelompok pendatang yang menjadi penyebab masalah. Kedua kejadian ini dapat dikaitkan dengan masalah ketenagakerjaan yang ada. Masyarakat yang tidak memiliki pekerjaan secara otomatis akan mengalami sebuah tekanan terhadap keadaannya. Untuk memenuhi kebutuhannya, mereka cenderung melakukan kejahatan seperti pencurian. Pekerjaan yang dimiliki juga terkena dampak dari ketidakseimbangan yang ada pada tingkat pendidikan dan pelatihan yang kurang. Hal ini menurunkan tingkat persaingan yang ada, sehingga mendorong peningkatan kejahatan yang dilakukan oleh kelompok imigran (Reich 2006, 94). Kejahatan yang terjadi juga merupakan dampak dari kurangnya integrasi pada lingkungan yang baru. Hal ini membuat individu tidak memiliki rasa tanggung jawab terhadap lingkungan yang ada, tidak mampu merasakan identitas yang berbeda, dan tidak dapat menyesuaikan serta memberikan respons terhadap masyarakat yang ada di sekitarnya (Eckert 2006, 24).

Sentimen terhadap Muslim juga memengaruhi kebijakan yang diterapkan oleh pemerintah Polandia. Pemerintah Polandia melihat bahwa keberadaan para pengungsi merupakan sebuah beban tersendiri 
(Bachman 2016). Keberadaan imigran sebagai solusi terhadap angka penduduk yang berkurang juga tidak diperhatikan. Hal ini dikarenakan oleh adanya pandangan yang negatif di kalangan masyarakat Polandia terhadap imigran. Pandangan yang menempatkan imigran sebagai penyebab berbagai permasalahan ini dibentuk oleh pemerintah Polandia. Pemerintah, bagaimanapun, bukan merupakan satu-satunya aktor yang dapat membentuk persepsi yang ada. Muncul pula aktor yang berpengaruh seperti media, yang berperan dalam membentuk pandangan masyarakat terhadap para pengungsi. Dalam hal ini, media dapat membuat berbagai berita yang menunjukkan kejahatan-kejahatan yang terjadi. Cara penyajian yang dimiliki memiliki pengaruh terhadap peningkatan emosi yang dimiliki oleh penonton terhadap konten yang dijadikan. Bentuk penyajian seperti ini menyebabkan munculnya persepsi bahwa tingkat kejahatan mengalami peningkatan, khususnya kejahatan yang terkait dengan keberadaan imigran. Hal ini dapat berpengaruh terhadap persepsi masyarakat terhadap kenaikan angka kejahatan yang ada, meskipun keadaan yang ada di lapangan menunjukkan adanya penurunan angka kejahatan (Pfeiffer, Windzio, dan Kleimann 2006, 117).

Persepsi yang ada ini dapat memengaruhi kebijakan yang ada. Keputusan dalam pembagian tanggung jawab terhadap pengungsi yang datang merupakan keputusan yang dimiliki oleh UE secara utuh. Hal ini, bagaimanapun, dipandang tidak sesuai dengan keinginan masyarakat Polandia dan dipandang sebagai suatu kemunduran. Keputusan ini dianggap sebagai suatu kemunduran karena menunjukkan ketidakmampuan negara untuk mengatur dirinya sendiri di bawah badan supranasional (Bachman 2016). Hal ini kemudian menimbulkan kekhawatiran di pemerintahan. Penyebab dari kekhawatiran tersebut tidak lain adalah berkurangnya kepercayaan terhadap pemerintah, yang dipandang oleh pemerintah sebagai keadaan yang tidak menguntungkan. Dampak dari hal tersebut dapat dilihat pada kebijakan yang diambil oleh pemerintah. Untuk mendapatkan dukungan yang kuat dari masyarakat, pemerintah cenderung mengambil keputusan yang memberatkan untuk para imigran dengan tujuan untuk mencegah terjadinya kejadian-kejadian yang berdampak buruk pada negara. Hal yang sama juga terjadi di pemerintahan yang baru, sehingga pentingnya dukungan yang kuat dari masyarakat menjadi salah satu kunci dalam pengambilan kebijakan yang dilakukan oleh pemerintah negara tersebut (Pfeiffer, Windzio, dan Kleimann 2006, 121). Pada bagian akhir ini, penulis melihat bahwa masalah yang muncul adalah adanya asosiasi pengungsi yang mengganggu stabilitas keamanan negara terhadap dikotomi imigran dan khususnya tenaga kerja.

Dari penjelasan di atas, penulis dapat menyimpulkan bahwa proses imigrasi dapat menyebabkan insekuritas dikarenakan beberapa faktor, 
yaitu: 1) faktor lingkungan; 2) budaya dan identitas; 3) pendidikan; 4) adanya asumsi "Trojan Horse"; serta 5) ketidakpuasan penduduk lokal. Penulis menekankan bagaimana suatu insekuritas dapat tercipta karena adanya ketimpangan dalam faktor-faktor yang yang telah disebutkan sebelumnya antara penduduk lokal dan migran dalam suatu segara. Selain itu, dengan asumsi "Trojan Horse", warga asli akan cenderung melihat migran sebagai suatu risiko yang mengancam. Migrasi membuka kemungkinan untuk terjadinya marjinalisasi dan berkurangnya struktur sosial dalam masyarakat, sedangkan penolakan masyarakat kepada para migran mendorong kelompok migran tersebut untuk membangun identitas mereka sendiri guna memperoleh rekognisi. Faktor penting bagi imigran agar dapat melebur dalam masyarakat adalah sense of belonging, respek, dan status yang jelas di lingkungan. Dari sini nampak bahwa faktor kultural sangat berperan penting untuk menggambarkan relasi antara "kita" dan "mereka", yang konstruksinya mendorong segregasi masyarakat Polandia.

Selanjutnya, dalam migrasi terdapat beberapa aspek yang menjadi faktor penarik para migran untuk bermigrasi ke suatu negara, yaitu: 1) geografis; 2) ekonomi; dan 3) budaya dan sosial-politik. Terdapat pula faktor pendorong, seperti ancaman yang diterima migran di negara asal. Hal ini menunjukkan bahwa masalah kultural bukan merupakan satusatunya alasan migrasi menjadi sebuah masalah. Pandangan yang terlalu menonjolkan alasan budaya dalam isu migrasi yang dihadapi oleh Polandia hanya akan menciptakan generalisasi terhadap permasalahan migran yang ada. Permasalahan mengenai migran tentunya berbeda di setiap negara, utamanya antara negara maju dan berkembang, sehingga tidak dapat dipukul rata dengan generalisasi bahwa masalah migran yang ada disebabkan oleh budaya. Permasalahan yang disorot harus terlebih dahulu jelas dan spesifik, sehingga dapat ditentukan apakah permasalahan yang ada disebabkan oleh faktor budaya, ketimpangan keahlian antara warga asli dan imigran, kebijakan pemerintah host country, atau alasan lainnya.

Penulis beropini bahwa terdapat terminologi yang patut dipahami terlebih dahulu, sebab migrasi tidak selamanya mengenai isu keamanan dan dapat dikaitkan dengan Hubungan Internasional. Migrasi menjadi bagian dari isu keamanan ketika migrasi mulai dipandang sebagai suatu risiko. Kita juga tidak dapat mengesampingkan dampak positif dari adanya migrasi. Dari studi kasus Polandia mengenai ketenagakerjaan, dapat diketahui bahwa negara maju membutuhkan lebih banyak tenaga kerja untuk mengisi lapangan kerja kasar. Kebutuhan tersebut dapat terpenuhi dengan adanya para migran. Migrasi pada awalnya bukan merupakan isu keamanan, namun kemudian mengalami politisasi sehingga akhirnya menjadi isu keamanan. Situasi yang pada awalnya normal kemudian digeser menjadi isu yang perlu dibahas dalam level 
pemerintahan. Proses politisasi tersebutlah yang menimbulkan dinamika yang mengubah migrasi menjadi ancaman potensial. Begitu pula yang terjadi dengan dinamika keamanan Polandia, di mana urgensi imigran tertantang dengan sekuritisasi imigran. Sekuritisasi yang mengasosiasikan para pengungsi dengan permasalahan domestik yang dihadapi negara tersebut dapat menimbulkan segregasi masyarakat dan merugikan negara. Hal ini disebabkan oleh adanya persepsi yang memandang imigran sebagai benalu bagi negara, yang dalam hal ini menambah permasalahan krisis tenaga kerja.

\section{Referensi}

\section{Buku}

Eckert, Roland, 2006. "Culture or Conflict? Migration, Culture Conflict and Terrorism", dalam Freilich, Joshua D. dan Rob T. Gurette (eds.). Migration, Culture Conflict, Crime and Terrorism. Burlington: Ashgate Publishing.

Freilich, Joshua D. dan Rob T. Gurette, 2006. Migration, Culture Conflict, Crime and Terrorism. Burlington: Ashgate Publishing.

Parkes, Roderick, 2015. Migration: New 'Push' and 'Pull' Dynamics. Brussels: European Union Institute for Security Studies.

Pffeifer, Christian, Michael Windzio, dan Matthias Kleimann, 2006. "Media, Evil and Society: Media Use and Its Impacts on Crime Perception, Sentencing Attitudes and Crime Policy in Germany" dalam Freilich, Joshua D. dan Rob T. Gurette (eds.). Migration, Culture Conflict, Crime and Terrorism. Burlington: Ashgate Publishing.

Reich, Kerstin, 2006. "Immigration and Juvenile Delinquency in Germany" dalam Freilich, Joshua D. dan Rob T. Gurette (eds.). Migration, Culture Conflict, Crime and Terrorism. Burlington: Ashgate Publishing.

Tonry, Michael, 1997. "Ethnicity, Crime, and Immigration", dalam Tonry, Michael (ed.). Crime and Justice, Volume 21: Comparative and Cross-National Perspectives on Ethnicity, Crime, and Immigration. Chicago: The University of Chicago Press.

\section{Jurnal Akademik}

Behtane, Ewa-Sowa, 2016. "Social Inclusion of Foreigners in Poland", dalam Konferensi $14^{\text {th }}$ Annual International Conference of the Bulgarian Comparative Education Society, 14-17 Juni. Sofia: Bulgarian Comparative Education Society.

Kennan, John, 2016. "Open Borders in the European Union and Beyond: Migration Flows and Labor Market Implications", NBER 
Working Paper Series No. 23048. Cambridge: National Bureau of Economic Research.

\section{Artikel Daring}

Bachman, Bart, 2016. "Diminishing Solidarity: Polish Attitudes toward the European Migration and Refugee Crisis". Migration Policy [online].

Dalam

https://www.migrationpolicy.org/article/diminishing-solidaritypolish-attitudes-toward-european-migration-and-refugee-crisis [diakses 8 Juni 2018].

Bartyzel, Dorota, 2018. "Poland in Labor Bind So Bad It Can't Staff JobPlacement Offices", Bloomberg [online]. dalam https://www.bloomberg.com/news/articles/2018-04-05/polandin-labor-bind-so-bad-it-can-t-staff-job-placement-offices. [diakses 9 Juni 2018].

Chapman, Annabelle, 2016. "Poland quibbles over who's a refugee and who's a migrant", Politico [online]. dalam https://politico.eu/article/poland-quibbles-over-whos-a-refugeeand-whos-a-migrant-beata-szydlo-asylum-schengen [diakses 9 Juni 2017].

Cienski, Jan, 2017. "Why Poland doesn't want refugees", Politico [online]. dalam https://www.politico.eu/article/politicsnationalism-and-religion-explain-why-poland- doesnt-wantrefugees [diakses 9 Juni 2018].

Dearden, Lizzie, 2017. "Poland's Prime Minister says country will accept no refugees as EU threatens legal action over quotas", The Independent [online]. dalam https://www.independent.co.uk/news/world/europe/poland-norefugees-eu-legal-action- infringement-quotas-resettlementbeata-szydlo-commission-a7741236.html [diakses 9 Juni 2018].

Euronews, 2018. "Poland refuses Middle Eastern migrants" [online]. dalam http://www.euronews.com/2018/o1/o2/poland-refusesmid-east-migrants [diakses 8 Juni 2018].

European Commission, 2018. "EURES The European Job Mobility Portal: Labour market Information", European Commission [online]. dalam https://ec.europa.eu/eures/main.jsp?catId=2789\&countryId=PL\& acro $=$ lmi\&lang $=$ en\&regionId $=$ PLo\&nuts2Code $=\% 20$ \&nuts 3 Code $=$ \&regionName=National\%20Level [diakses 9 Juni 2018].

Harper, Jo, 2018. "Poland fears economic hit as EU opens door to Ukrainians", Deutsche Welle [online]. dalam http://www.dw.com/en/poland-fears-economic-hit-as-eu-opensdoor-to-ukrainians/a-42367764 [diakses 9 Juni 2018].

Human Rights Watch, 2017. "Poland: Asylum Seekers Blocked at Border" [online] dalam 
https://www.hrw.org/news/2017/03/01/poland-asylum-seekersblocked-border [diakses 9 Juni 2018].

Iglicka, Krystyna dan Magdalena Ziolek-Skrzypczak, 2010. "EU Membership Highlights Poland's Migration Challenges", Migration Policy Institute [online]. dalam https://www.migrationpolicy.org/article/eu- membershiphighlights-polands-migration-challenges [diakses 8 Juni 2018].

Koper, Anna dan Pawel Florkiewicz, 2017. "Poland faces labour shortage for EU-funded infrastructure work in 2018 2020-CEO", Reuters UK [online]. dalam

https://uk.reuters.com/article/ferrovial-budimexworkers/poland-faces-labour- shortage-for-eu-fundedinfrastructure-work-in-2018-2020-ceo-idUKL8N1IV28T [diakses 9 Juni 2018].

Radio Poland, 2018. "Migration policy decisions up to EU members: Polish PM in Budapest" [online]. dalam http://www.thenews.pl/1/10/Artykul/342582,Migration-policydecisions-up-to-EU-members-Polish-PM-in-Budapest [diakses 9 Juni 2018].

Shah, Shakhil, 2018. "Labour Shortage Forces Poland to Open Borders", Emerging Europe [online]. dalam https://emergingeurope.com/in-brief/labour-shortage-forces-poland-to-openborders [diakses 9 Juni 2018].

The Associated Press, 2017. "Poland, Hungary leaders persist with antimigrant policies", The Star [online]. dalam https://www.thestar.com/news/world/2017/o9/22/polandhungary-leaders-persist-with-anti-migrant-policies.html [diakses 9 Juni 2018].

UNHCR, 2016. "UNHCR Factsheet on resettlement: Syrian Refugees", UNHCR [online]. dalam https://www.unhcr.org/59364f887 [diakses 9 Juni 2018].

Wasik, Zosia, 2016. "Poland weights benefits of surge in migrants from Ukraine", Financial Times [online]. dalam https://www.ft.com/content/aeda9ebe-3afa-11e7-ac89bo1cc67cfeec [diakses 9 Juni 2018].

\section{Video}

Cragg, Gulliver, 2018. Why Ukrainian workers are flocking to Poland [video]. Warsawa: France24. 